\title{
台北市大稲埕地区における歴史的環境保全計画に関する研究 STUDY ON HISTORIC ENVIRONMENT CONSERVATION PLAN OF DA-DAO-CHENG DISTRICT IN TAIPEI
}

\author{
林 美 吟*, 浅野 聁**, 浦 山 益郎*** \\ Meiyin LIN, Satoshi ASANO and Masurou URAYAMA
}

\begin{abstract}
Da-Dao-Cheng district, with various kinds of historic shop-houses, is located in Metropolis of Taipei. The conservation movement by the citizens, NPOs, and experts began with the road-widening urban plan on the main street, Di-Hwa Street, and led to the change of policies to conservation. The conservation plan was officially announced in 2000 after various discussions, by designated as a special district with the use of system of Transfer of Development Rights. This paper discusses the achievement and issues of the conservation plan, by analyzing the process of plan making, changing of conservation proposals, and the current operations.
\end{abstract}

Keywords: Taipei, Da-Dao-Cheng, Historic Environment, Conservation Plan, Special District, Transfer of Development Rights 台北市, 大稲㘿, 歴史的環境, 保全計画, 特定専用区, 容積移転

1. 研究の背景·目的及び方法

(1) 研究の背景

台北市の大稲埕(Da-Dao-Cheng) 地区（図 1) は、清時代の 1851 年 から発展してきており、日本統治時代（1895 年〜1945 年）を経て多 様な伝統的街屋 (注1) が現存している地域である。1977 年に大稲埕 地区内における主要な街路である迪化街 (社2) (Di-Hwa Street)にお いて「変更迪化街寬度案」(迪化街の幅を変更する計画。以下、拡幅 計画) が策定され、約 $7.8 \mathrm{~m}$ から $20 \mathrm{~m}$ に道路幅員を拡幅することが計 画されたことを契機に、専門家などによって街並み保全の提唱が始 まった。1984 年に台北市都市計画担当部局は、都市計画法に基つい て、「特定専用区」(注3) の指定に向けての街並み保全計画を検討し始 めたが、拡幅計画の変更にまでは至らなかった。1988 年には拡幅事 業が実行される直前に、住民、NP0 及び専門家によって多くの保全

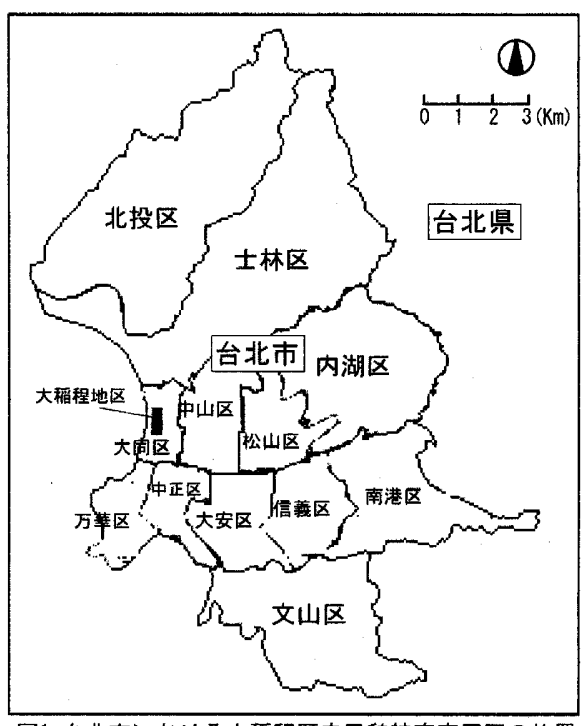

図1 台北市における大稻程歴史風貌特定専用区の位置
運動が行われ、

その結果、台北 市政府は拡幅事 業を延期し、計 画の再検討をす ることとなった。 1989 年以降、専 門家や NP0 など の協力のもと、 大稲㘿地区に対 して本格的な調 査が行なわれ、 以後、様々な保 全計画案が検討 された。そして 2000 年 1 月には、
1977 年の拡幅計画が都市計画法に基づいて変更され(注4)、現在の「大 稲埕歴史風貌特定専用区計画」(以下、2000 年計画と略す) (注:5) が 策定されることとなった。

台湾における歴史的環境の保全に関する現行制度は、主に文化凟 産保存法（以下、文資法）によって「古蹟」、「歴史建築」或いは「保 存区」の指定などを行うものである。しかし、それらの関連制度が まだ十分に整備されていない(注6)ため、近年、都市計画制度などを 用いた保全事例が増えてきている(拄7)。台北市大稲埕地区の事例は、 特定専用区や容積移転（TDR：Transfer of Development Rights）制 度 (注8) などを適用している点で台湾の歴史的環境保全においては先 駆的事例であり、また都心部に㧍ける一つの重要な参考事例になる と考えられる。

大稲埕地区に関する国内の既往研究は、建築様式などに関する研 究があり (注9)、台湾における既往研究は、後述する大稻埕地区の保、 全計画案に関する報告書が中心であり(注 10)、本研究の対象とする保 全計画案の変遷及び保全概況の分析については、十分な研究が行わ れていない。なお、1980年〜1990 年にかけて策定された保全計画案 の変遷については、筆者らの研究が先鞭をつけてきている(注11)。

(2) 研究の目的と研究の方法

(1) 研究の目的

本研究任、台北市大稲㘿地区を対象に、1977 年の拡幅計画から現 在までの歴史的環境保全の取り組みの経緯、歴史的環境保全計画案 の変遷及び現行の保全計画内容及び運用概況を整理把握すると共に、 その特徵と課題について考察することを目的としている。，

\section{(2) 研究の方法}

前述の研究目的を明らかにするため、台北市政府都市発展局大同 区都市更新工作室（前身は「迪化街工作室」である）に対する文献 調查、ヒアリング調查及び大稲坦地区における現地調査を行った。 また適宜、専門家及びNPOに対してヒアリング調查を行った (注 ${ }^{12)}$ 。
* 三重大学大学院工学研究科 博士後期課程 $\cdot$ 工修 ** 三重大学工学部建築学科 助教授. 工博 *** 三重大学工学部建築学科 教授. 工博
Graduate Student, Graduate School of Mie Univ., M. Eng. Assoc. Prof., Dept. of Architecture, Faculty of Eng., Mie Univ., Dr. Eng. Prof., Dept. of Architecture, Faculty of Eng., Mie Univ., Dr. Eng. 


\section{2. 大稲埕地区の概要}

（1）市街地発展史 (注 13)

大稲埕地区は、艋䑧地区（現在の台北市万華区）及び台北城内地 区とともに台北市で最も発展が早かった地区の 1 つである。1851 年 から市街地として発展し始め、1885 年〜1895 年の間に、新たな河 港として位置づけられ、また外国人居留地の設立や鉄道の建設など によって茶・樟脳の集散地及び海外との貿易の中継点として全盛期 を迎えた。日本統治時代に入ると、日本との貿易が増加するに伴い、 大稲埕地区は植民地下における農業・工業製品の流通の中心地とな った。1905 年には、「台北市区改正計画」が制定され、1910 年の大 稲埕地区の市街地整備に伴い、建て替えによって街屋の立面に当時 の日本でも進んでいた欧風化のデザインが遒入された。

戦後、国民党政府の渡台により、台北市は中華民国の第一都市と なり、1950 年代に行われた道路整備事業によって、大稲㘿地区と台 北城内地区の交通状況が改善され、地区内の中小企業がさらに発展 することとなった。1966 年に台北市が中央政府の直轄市となり、そ の後の都市発展によって市の商業的中心が台北市の東側に移り、大 稲埕地区は旧市街地となったが、問屋町として伝統的な建築物や産 業形態が今日まで維持されてきている。

\section{（2）地区の概要}

2000 年計画によると、大稲㘿地区の概要は下記の通りである。 (1) 計画範囲 : 計画範囲は、図 2 に示すように、民権西路、延平北路 東側の $30 \mathrm{~m}$ まで、南京西路南側の $30 \mathrm{~m}$ まで、環河北路一段を境にす る地域であり、面積は 26.1haである。

(2) 迪化街沿道の地域区分: 迪化街沿道の歴史街区は 5 つの東西方向 の道路により、北区（民権西路から涼州街まで）、中北区（涼州街か ら帰綬街まで)、中区（帰綏街から民生西路まで）、南区（民生西路 から南京西路まで）の4つの地域に大別できる。

(3) 人口: 16,749 人。

(4) 産業: 布業、漢方薬業、雑貨業が地区の 3 大産業であり、南区は 布業、中区漢方薬業、中北区は雑貨業が集中している。北区の産 業は現在衰退している。

\section{(3) 歴史的環境}

現在、地区内においては、国指定古蹟の霞海城隍廟及び市指定古 蹟の宰顯栄宅のほか、台北市政府によって迪化街沿道の歴史街区に 約 77 棟の街屋建築が「歴史性建築」(注 14) として認定されている。

街屋の空間構造は図 3 に示すように、街路に面して騎楼 (Chi-Lo, アーケード）が設けられ、その後に第 1 進 (注 15)（店舗、居間など）、

第 2 進（祭祀、倉庫など）、第 3 進（工場など）が続き、進と進の間 には中庭が設けられる。迪化街沿道の街屋建築の規模は第 2 進〜第 4 進、高さは 2 3 層が多い。立面の様式は写真 1 のように、閩南 (Min-Nan, 福建南地方) 式、洋楼式、バロック式及び近代建築式の 4 つに大別され、閩南式は迪化街の中北区、中区に、洋楼式は北区 に、バロック式は中区及び南区に多い。また、近代建築式は計画地 区全域に散在している(注16)。

\section{3、大稻埕地区の歴史的環境保全の取り組みの経緯}

大稲㘿地区の歷史的環境保全の取り組みの経緯は、前述の通り、 1977 年の拡幅計画から始まり、住民、NP0、専門家及び行政による 取り組みについては、図 4 に示すように 4 つの時期に大別できる。

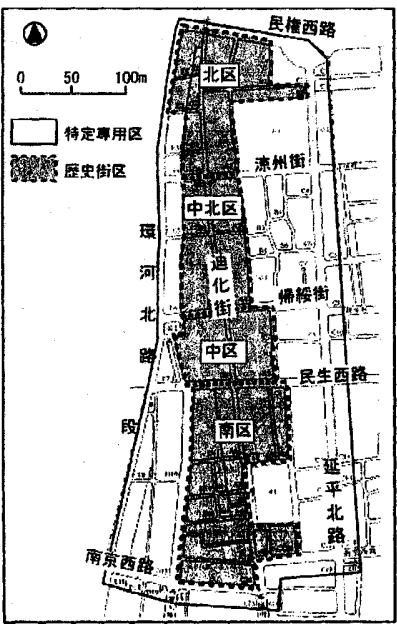

図2迪化街沿道における地域区分

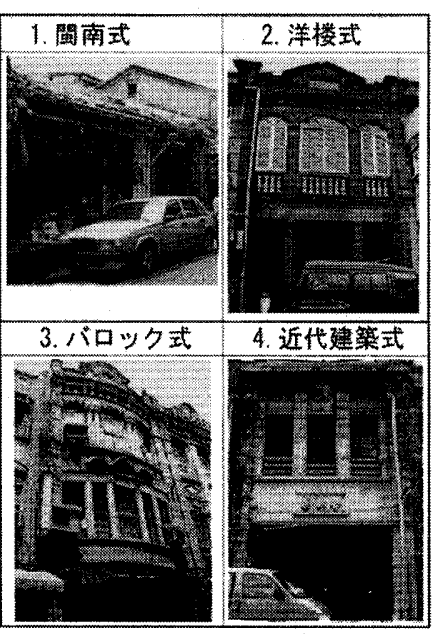

写基 1 立面における建築様式
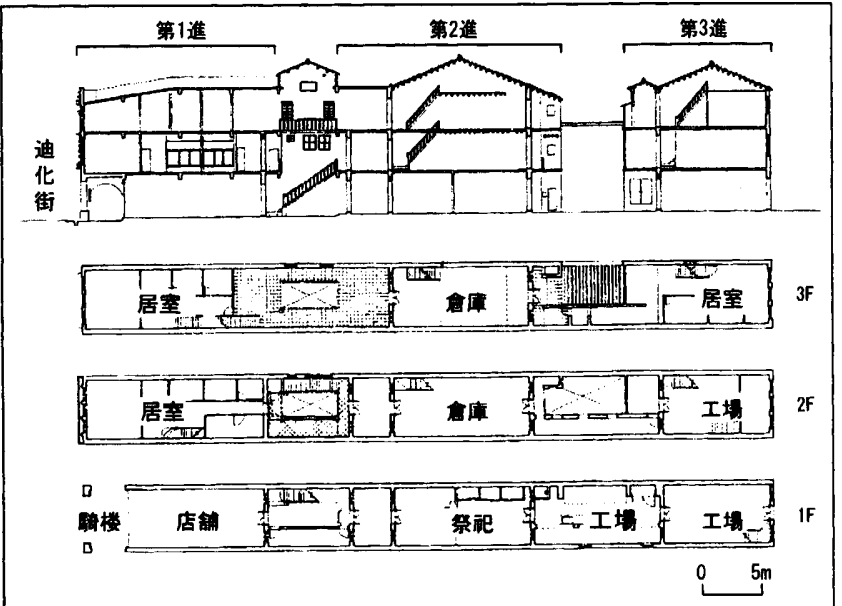

図3 街屋の空間凓造 (平面図・断面図)

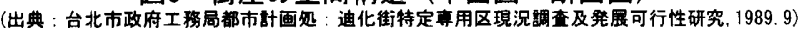
（1）拡幅計画再検討期（1977 年〜1988 年）

1977 年に迪化街に㧈ける拡幅計画が策定されたことにより、台北 市政府工務局新建工程処は、この計画に基づき、沿道の一部の土地 買収を行つた。

1983 年には、迪化街沿いの永楽市場の建て替えを行い、拡幅計画 に従ってセットバックしたため、迪化街の街並み景観に影響を与え てしまった。それを契機に、住民や専門家などによって迪化街の歴 史的環境保全が提唱された。一方、拡幅計画に基づき、迪化街の西 側が住宅地とされ、東側が商業区とされたため、異なる土地利用の 設定により、地域の全体性が無視されていることが指摘された。

これらの状況に応じて、台北市都市計画委員会（以下、市都市計 画委員会）は迪化街を対象とした特定専用区の指定に対する検討を 行った。1984 年、台北市工務局都市計画処（以下、市都市計画課） は大稻㘿地区に対する初の保全計画案である「迪化街特定専用区都 市設計之研究一伝統市街風貌重建計画一」(迪化街特定専用区におけ る都市設計に関する研究一伝統的市街地の風貌を再建する計画一。 以下、1984 年案) を策定し、翌年、1984 年案の計画範囲の建築物に 対して高さ、立面、材料などの規制に関する「迪化街特定専用区未 完成法定程序前建築注意事項」（迪化街特定専用区における法定手 続きの完成前の建築物に対する注意事項）を制定、公表したが、工 務局内部の決定事項であり、法的強制力がなかったため、実際に運 用するまでには至らなかった。 


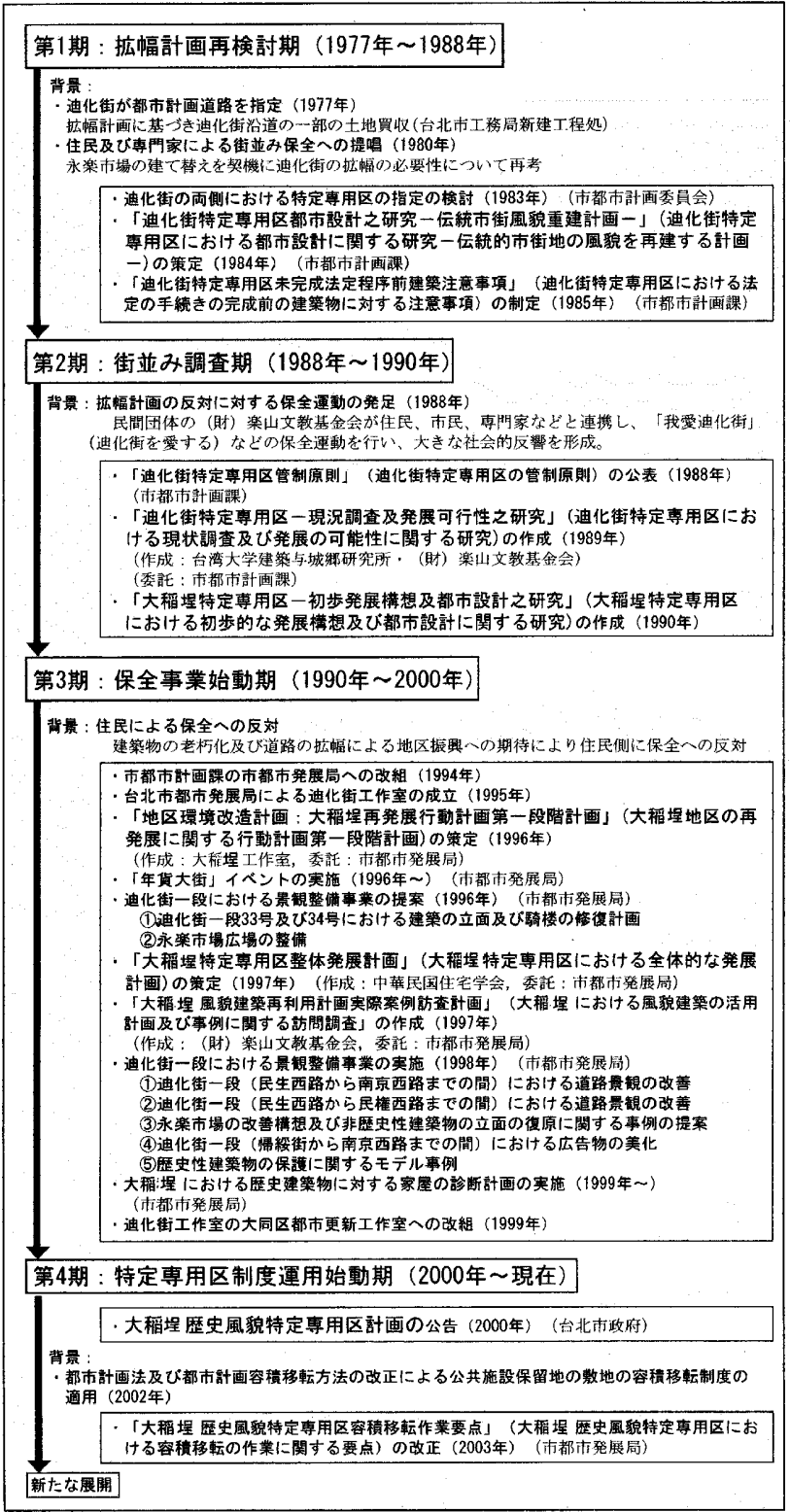

图 4 大稲埕地区の保全経緯 (注 17 )

（2）街並み調査期（1988 年〜1990 年）

1988 年 7 月には、拡幅事業が実行される直前に民間団体の（財） 楽山文教基金会が住民、台北市民、専門家などと連携し、「我愛迪化 街」（迪化街を愛する）などと名付けられた保全運動を展開し、社会 的に大きな反響を呼ぶこととなった。その結果、市都市計画委員会 は同年 11 月に迪化街の街並みを特定専用区に指定する必要性を示 し、拡幅計画の代案を策定すると共に、一時的措置としての「迪化 街特定専用区管制原則」（迪化街特定専用区の管制原則）公表した。 それに伴い、台北市都市設計審議委員会 (以下、市都市設計審議会) (注 18) によって大稲㘿地区における土地利用、建築物の高さ、現存 の建築物の保存と修景、新築及び増改築などが審查されることとな った。

市都市設計審議会の審查により、都市設計制度 (注 19) が歴史的街 並みの保全に初めて適用されたが、この管制原則は一時的措置であ るため、市都市計画課は建築物の建て替えの際に、その所有者とケ 一ス・バイ・ケースで協議を行うこととなっていた。

1989 年、市都市計画課は台湾大学及び（財）楽山文教基金会に委
託して大稲㘿地区の街並みに対寸る本格的な調查を行い、迪化街特 定専用区一現況調查及発展可行性之研究」(迪化街特定専用区にお计 る現状調査及び発展の可能性に関する研究。以下、1989 年調查)を 作成した。翌年、さらに市都市計画課は中原大学に委託し、「大稲埕 特定専用区一初歩発展構想及都市設計之研究」(大稲㘿特定専用区に おける初歩的な発展構想及び都市設計に関する研究。以下、1990年 案)が作成され、街並みの保全に対する補償としての容積移転制度の 適用について初めて提案されることとなった。

（3）保全事業始動期（1990 年 2000 年）

市都市計画課は 1990 年案の提案を踏まえ、歴史的環境の保全を目 的とする特定専用区計画の策定にとりかかったが、建築物の老朽化、 建築物の規制に対する補償措置の久如、及び道路の抗幅による地区 振興への期待により、住民側に保全反対の声が上がってきた。

これに対して、1993 年に市都市計画課から改組された台北市政府 都市発展局（以後、市都市発展局）は、1995 年に住民の意見聴取や 計画案の説明のための、「迪化街工作室」を永楽市場の 5 階に設置し、 市職員を常駐させるようにした。そして、1994 年に保全の関心を持 っている学生や市民が結成した「大稲㘿工作室」と連携し、1995 年 に同局による住民主体の身近な環境の改善を目的として創設された 「地区環境改造計画」事業を運用し、1996 年には「地区環境改造計 画 : 大稲埕再発展行動計画第一階段計画」(大稲㘿地区の再発展に関 する行動計画第一段階計画。以下、1996 年案)を策定した。また、 住民との連携で「年貨大街」(注 20) のイベントを行うと共に、容積移 転制度、交通の改善、大稲㘿地区の産業振興、環境整備などに対す る様々な提案を行った。

1997 年には、市都市発展局が中華民国住宅学会に委託し、1984 年から提案されている一連の計画案を再考し、「大稲㘿特定専用区 整体発展計画」(大稲埕特定専用区における全体的な発展計画。以下、 1997 年案)を策定した。そして1998 年1月には、市都市発展局は 1997 年案の計画内容を参考にして、歴史性建築の保存、都市設計制度及 び容積移転制度などに重点をおいた「大稲㘿特定専用区計画」（案） を策定し、市民に 45 日間公開して公聴会も行った。それに伴い、迪 化街工作室によって迪化街を対象に永楽市場広場の整備、路面の舗 装の改善、看板の整備などのハード面の景観整備事業や「年貨大街」 などのソフト事業が行われた。

\section{（4）特定専用区制度運用始動期（2000 年～現在）}

1998 年 7 月、大稲㘿特定専用区計画案が市都市計画委員会によっ て決定され、2000 年 1 月に「大稲埕歴史風貌特定尃用区計画」とし て公告されるに至った。2000 年計画の公告以後、歴史性建築の修復 及び容積移転の申請件数が増えてきている。その運用概況について は第 5 章に述べる。

\section{4. 大稲埕地区における歴史的環境保全計画案の変遷}

第 3 章において述べた通り、1984 年案の作成から 2000 年計画の 決定に至るまでに、合計 4 つの保全計画案、1 つの行動計画が検討 された。各計画案の策定時期、背景と目的、策定における住民参加、 計画範囲及び計画内容については表 1 に、また、各計画案における 範囲、ゾーニングについては図 5（1984 年案から 1997 年案まで）及 び図 6 (2000 年計画) に示す通りである。な挍、現行計画の 2000 年計画については、第 5 章に扔いて述べる。 


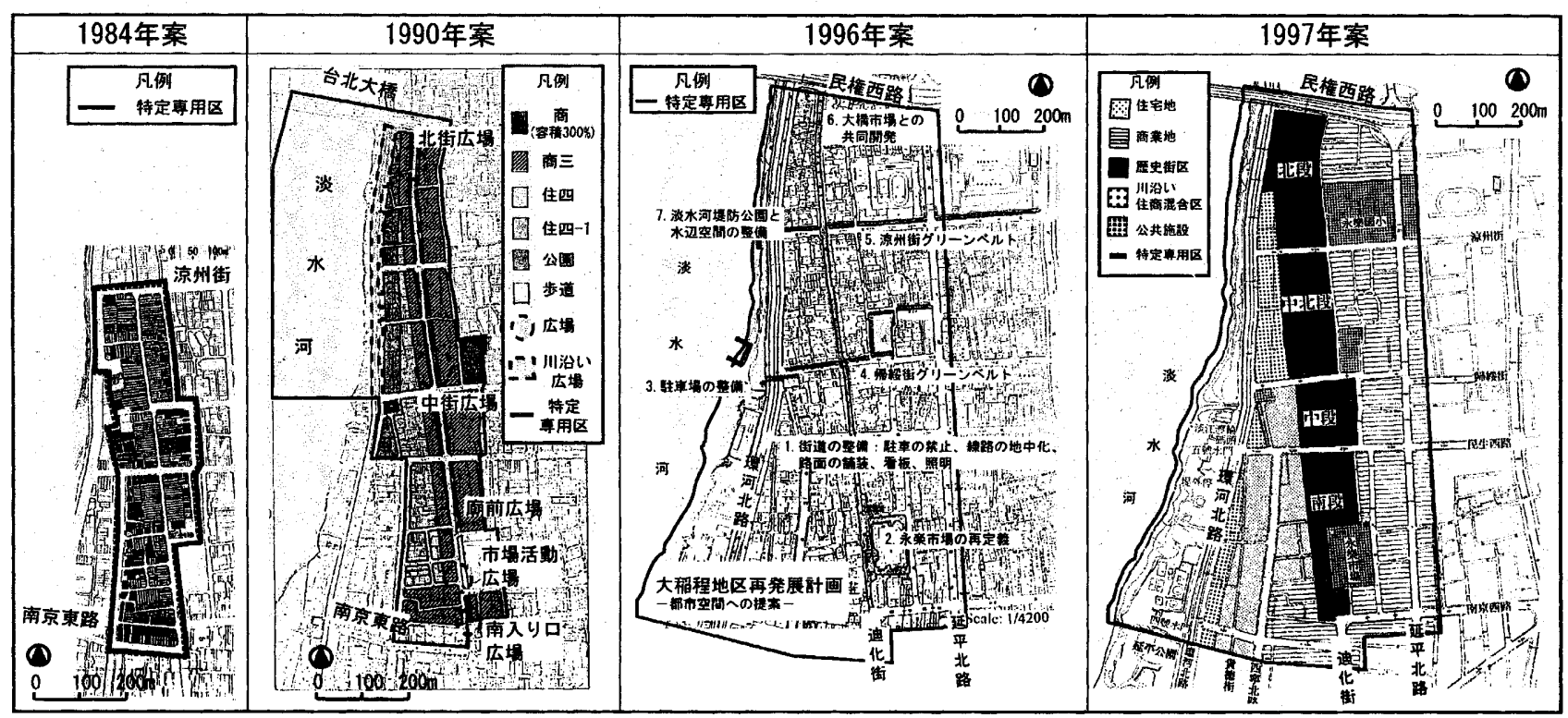

図5大稲埕地区における保全計画寀の変遷（1984年案から1997年案まで）

\begin{tabular}{|c|c|c|c|c|c|c|c|}
\hline \multirow{2}{*}{\multicolumn{3}{|c|}{ 項目 }} & 1984 年索 & & & & 2000 年然画 \\
\hline & & & 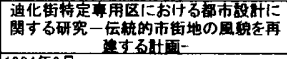 & 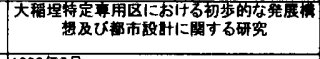 & 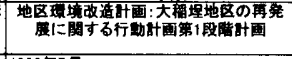 & 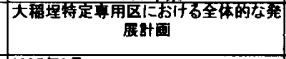 & 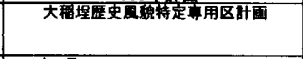 \\
\hline \multicolumn{2}{|c|}{ 策定機闌 } & & 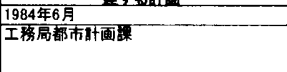 & 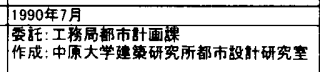 & 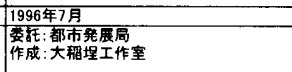 & 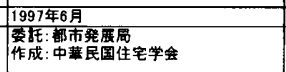 & \begin{tabular}{|l}
2000 年3月 \\
部市产展局
\end{tabular} \\
\hline \multicolumn{3}{|c|}{ 贯 量 } & 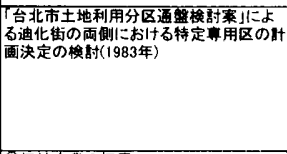 & 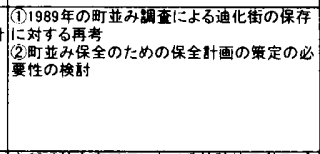 & 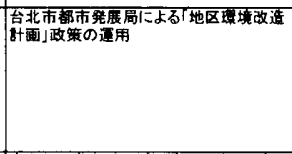 & 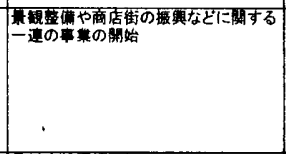 & 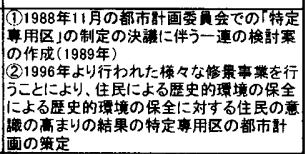 \\
\hline \multicolumn{3}{|c|}{ 目 的 } & 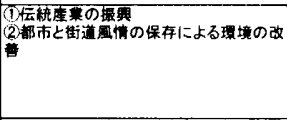 & 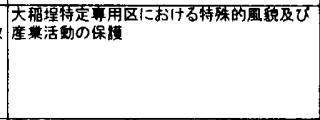 & 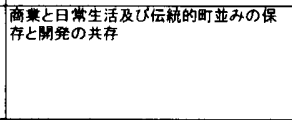 & 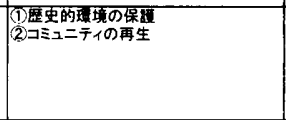 & 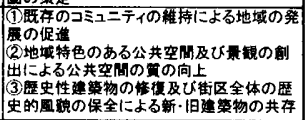 \\
\hline \multicolumn{3}{|c|}{ 策定における住民壹加 } & 迪化街一段の住民1対するアンケート理 & 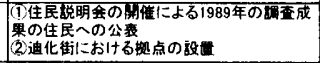 & 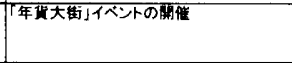 & アンケー下晍萳 & 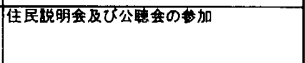 \\
\hline \multicolumn{3}{|c|}{ 箅 围 } & 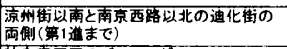 & 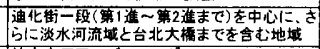 & 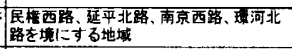 & 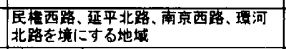 & 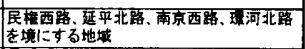 \\
\hline \multirow{2}{*}{\multicolumn{3}{|c|}{ 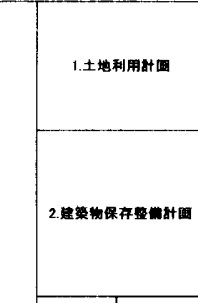 }} & 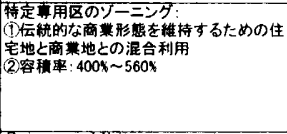 & 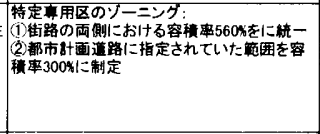 & 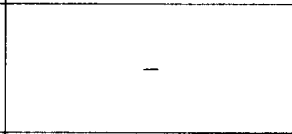 & 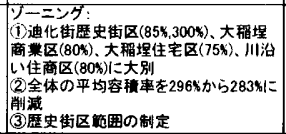 & 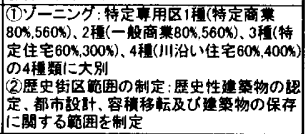 \\
\hline & & & 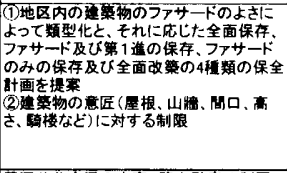 & & (1) & 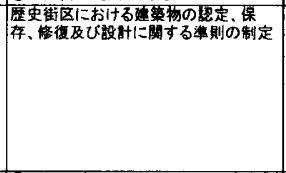 & 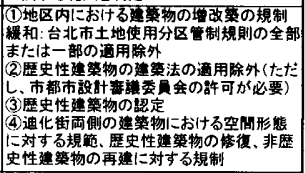 \\
\hline \multirow{11}{*}{ 計面 } & \multirow{9}{*}{ 3.地区㻴境 } & 交通 & 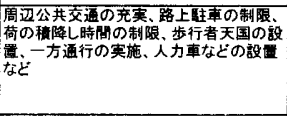 & 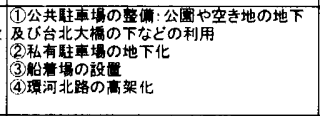 & 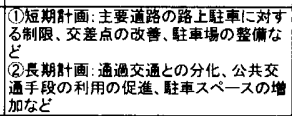 & 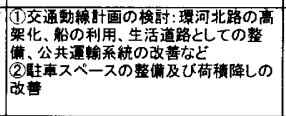 & - \\
\hline & & 略以 & - & - & 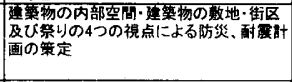 & 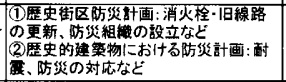 & - \\
\hline & & $\begin{array}{l}\text { オープスス } \\
\text { ベース }\end{array}$ & - & 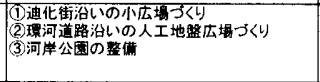 & - & 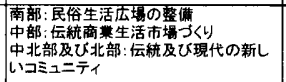 & - \\
\hline & & 公共施毅 & 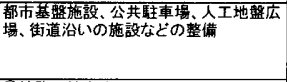 & 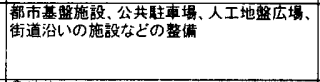 & 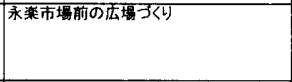 & 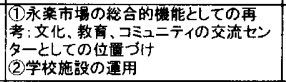 & 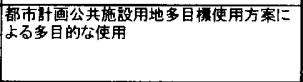 \\
\hline & & 苗路空闌 & 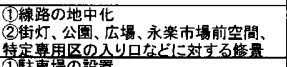 & 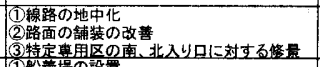 & 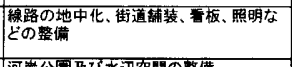 & 歴串街区の制定 & 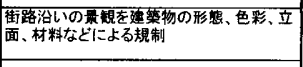 \\
\hline & & 水设空閣 & 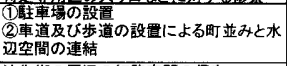 & 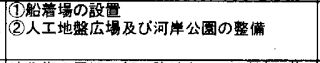 & 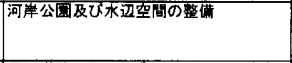 & 河革公園の整碳 & - \\
\hline & & 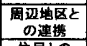 & 迪化街の周辺の細路垔間の保存 & 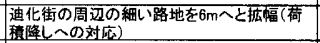 & 周辺道路におけるるグリーンバルトの整莄 & - & - \\
\hline & & 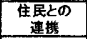 & 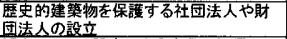 & - & 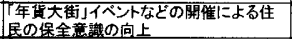 & - & - \\
\hline & & 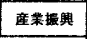 & 覾光ルートの設定による產業の掁興 & 伝統產業の店甜の家賢への補助 & 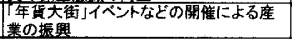 & 钼光の吐展、商店街の活珄化 & - \\
\hline & \multicolumn{2}{|c|}{ 5.助成措置 } & 建勧物保存部分に対する娍税措置の制 & 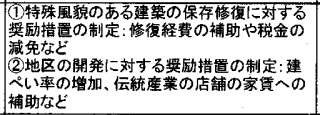 & - & 税金の澸免、財政の協力 & 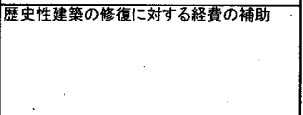 \\
\hline & \multicolumn{2}{|c|}{ 6.察掅移较 } & - & 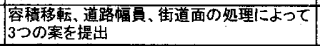 & 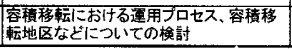 & 容䅡移轱、容積歰励 & 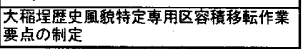 \\
\hline
\end{tabular}


（1） 1984 年案：迪化街特定専用区における都市設計に関する研究一

\section{伝統的市街地の風貌を再建する計画一}

1983 年に市都市計画委員会は、「台北市土地利用通盤検討案」（台 北市の土地利用に関する見直し計画案）在検討する際に、迪化街に 対する特定専用区の指定を提案した。これに対応して、市都市計画 課は建築物の保存状況、土地利用状況、住民意見などの調查を行い、 翌年、伝統産業の振興、都市及び街道風情の保全による環境の改善 を目的として 1984 年案を策定した。

計画範囲は、迪化街沿道の街屋建築の第 1 進までとしている。

計画内容は、まず迪化街を拡幅せずに伝統的商業形態を維持する ための住商混合の土地利用が提案された。建築物については、その 保存状況によって(1)全面保存、(2)立面及び第 1 進の保存、(3)立面の みの保存、(4)全面改筑の 4 つの保存形式が提案された。地区環境の 整備については、交通の改善、淡水河との連携、迪化街の周辺の細 街路の保全、保全団体の設立、建築物の保存に対する補助措置など の必要性が示されたが、具体的な提案までには至らなかった。

（2）1990 年案：大稲坆特定専用区における初歩的な発展構想及び都 市設計に関する研究

1988 年の保全運動を通して拡幅計画が延期され、翌年、市都市計 画課は（財）楽山文教基金会及び台湾大学建築与城郷研究所に委託 し、大稲埕地区に対する文献調查、現状調查、社会構造調查及び空 間調查を行い、1989 年調査が行われた。この調査を通じて大稲㙅地 区における歴史的環境保全の必要性が再確認されると共に、保全地 区の拡大及び名称の変更 (大稲㘿特定専用区に変更すること)、保全 計画の策定、住民参加の促進及び容積移転制度の運用などの構想が 提案された。そして、1990 年には、市都市計画課が中原大学建築研 究所都市設計研究室に計画案の作成を委託した。中原大学は、(財) 楽山文教基金会及び台湾大学建築与城鄉研究所と連携して住民説明 会を行い、上記の調查結果を公開した。その後、迪化街の建物を借 りて、約 10 週間に渡り情報提供の拠点としての「大稲埕全体計画工 作室」を設置し、住民意見などを収集しながら、特殊の風貌及び産 業活動の保護を目的とした 1990 年案を策定した。

1984 年案と比較すると、計画範囲は迪化街沿道から台北大橋及び 淡水河流域まで抎大しており、川などの周辺の景観を包括して保全 する考え方が初めて提案されている。

計画内容は、迪化街沿道の容積率の再考、都市設計管制規則の制 定による歷史的建築物の修復及び新築に対する立面や高さなどに関 する規制、船着場の設置による水上交通の改善、河岸公園及び迪化 街沿いの小広場の設置によるオープンスペースの整備、特殊風貌の ある建築の保存修復に対する奨励措置の制定、及び容積移転の実施 などのより具体的な提案が行われた。

（3）1996 年案 : 地区環境改造計画 : 大稲埕地区の再発展に関する行

動計画第一段階計画

前述の通り、市都市発展局は計画策定において住民との交流を促 進するために、1995 年に永楽市場に「迪化街工作室」を設立した。 同年、「大稲㘿工作室」に委託し、伝統的街並みと開発の共存を目的 とした 1996 年案を策定した。

計画範囲は民権西路、延平北路、南京西路、環河北路を境にする 地域となり、周辺地区の範用が 1990 年案より㹡大された。

計画内容としては大稲程地区においての現状の課題を早急に解決
するために、都市空閒の整備、容積移転制度の運用、交通・防災計 画の策定などが提案された。一方、地区の商業振興のため、行政及 び住民の連携により年一回の「年貨大街」イベントの実施などが提 案された。

\section{（4） 1997 年案：大稲埕特定専用区における全体的な発展計画}

1997 年に市都市発展局は整備事業などを行いながら、中華民国住 宅学会を通じて各分野の専門家に呼びかけ、1984 年以降の計画案を 再考するとともにアンケート調查や地元団体による住民意見の聴取 を行い、歴史的環境の保全及びコミュニティの再生を目的とした 1997 年案を策定した。

計画範囲は 1996 年案と同様であり、計画内容は土地利用計画、都 市設計管制要点の制定による歴史的建築物の保存、歴史街区の指定 による歴史的環境の保全、公共施設、オープンスペース、緑地、防 災、交通などの地域整備計画の策定、及び容積移転に関する要点の 制定による補償措置の制定などであり、大稲程地区全体に対する提 案となっている。

\section{2000 年計画の計画内容および運用概況}

2000 年計画の計画目的、発展構想、計画内容および運用概況につ いては、下記の通りである。

\section{(1) 計画目的}

計画の目的は、主に地域発展の促進、公共空間の品質の向上、歴 史性建築の修復及び新・旧建築物の共存である。

\section{(2) 計画内容}

歴史的環境保全に関する計画内容は、土地利用計画、歴史性建築 の諗定及び保存、歴史街区の範囲の設定、都市設計管制要点の制定、 容積の奨励及び容積移転制度、地区環境整備計画などに大別される。

\section{(1) 土地利用計画}

図 6-Aに示すように、迪化街を拡幅せずに、計画範囲にお汸る商 業区及び住宅区を特定専用区 1 種 (特定商業)、同 2 種 (一般商業)、 同 3 種 (特定住宅)、同 4 種（水辺住宅）(注 23) の 4 種類に変更し、 それぞれの建べい率及び容積率は表 1 の 2000 年計画に示す通りであ る。しかし、迪化街に隣接する敷地は、沿道景観の一体性を重視す るため、既存の道路線から $20 \mathrm{~m}$ までの敷地に対しては土地利用の種 別を問わず容積率 $390 \%$ を限とし、また、その建べ率は市都市設 計審議会の審議によって $85 \%$ まで緩和することができる。また、特 定専用区内の歷史性建築の場合は第 1 進までを最低限保存すること を条件として、その建ぺい率を市都市設計審議会の審議によって変 更することができる。

\section{(2) 歴史性建築の認定及び保存}

私有の歴史的建築物を保存するため、市都市発展局は「大稲㘿歴 史風貌特定専用区歷史性建築認定作業要点」(大稲㘿歷史風貌特定 専用区における歷史性建築の認定作業に関する要点）に基づいて歴 史性建築を認定することができる。歴史性建築は、市都市設計審議 会において「大稲㘿歴史風貌特定専用区都市設計管制要点」(大稲㘿 歴史風貌特定専用区における都市設計の管制要点。以下、都市設計 管制要点）に基づき建築物保護事業計画（以後、保護計画）が審議 された後に、建築物の復原或いは修復を行う。復原及び修復に対す る補助については台北市都市更新審議委員会（以下、市都市更新審 議会）において「台北市都市更新地区奨励歴史性建築維護補助及認 
定要点」（台北市都市更新地区における歴史性建築の認定及び保護 に対する補助に関する要点）に基づいて審議され、修復額全体の約 $50 \%$ 上限に補助することができる。歴史性建築の保存については、 保存された建築面積及び維持保護のコストに応じてその建築物の容 積を増加することができる。また、「大稲㘿歴史風貌特定専用区容積 移転作業要点」(大稲㘿歴史風貌特定専用区にお污容積移転の作 業に関する要点。以下、容積移転作業要点）による未使用容積の移 転がある。歴史性建築の分布状況については、図 6-B に示寸通りで ある。2004 年 7 月現在、 7 件の歴史性建築について容積移転の申請 と共に保護計画が提出され、全て市都市設計審議会の審議の上で全 面保存となっている(注24)。

\section{(3) 歴史街区の範囲の設定}

歴史的資源の保護及び民間の開発権益の確保のため、図 6-B に示 すように、歴史性建築の認定と保存、都市設計管制要点と容積移転 制度の運用などを目的として歷史性建築が集中する地域を「歷史街 区」として指定している。但し、その街区に対する具体的な保全計 画はまだ未策定である。

(4) 都市設計管制要点の制定

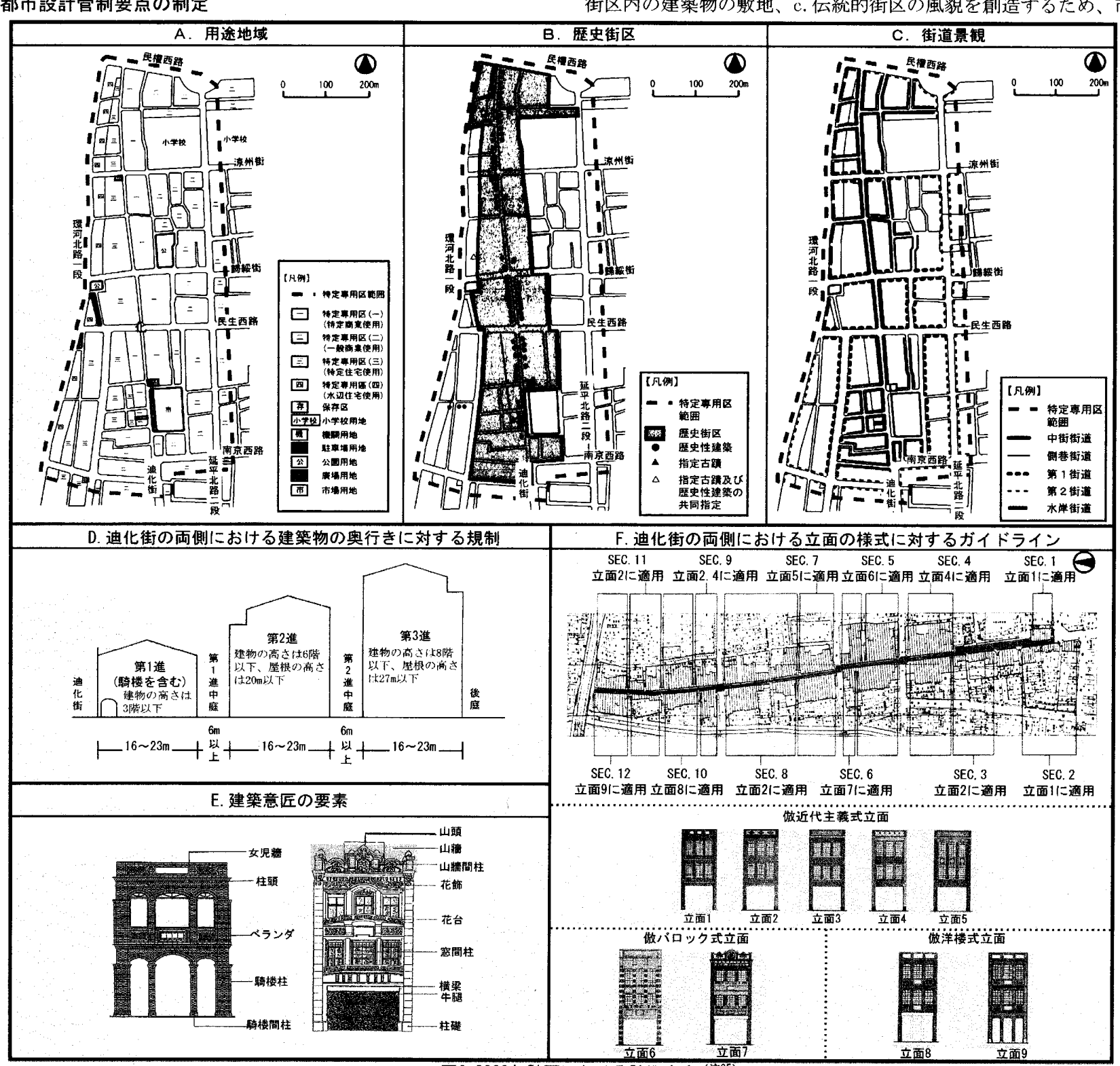

图6 2000年計画における計面内容
歴史性建築の保存及び街区独特の空間形態の保存のため、都市設 計管制要点を制定し、主に(1)歴史性建築物の保存及び非歴史性建築 物の新築、(2)迪化街の両側の建築物における空間形態、高さ及び立 面の意匠、(3)特定専用区内の街路沿いの景観などを規制している。 迪化街両側の建築物の新築に対して、その空間構成を図 6-D に示寸 ように第 1 進から第 3 進までを規制すると共に、その立面に対して は図 6-F に示すようにデザインガイドラインによって規制している。

また、特定専用区内の街路沿いの景観を、図 6-Cに示寸通り、産 業の特色によって、「中街街道 (迪化街の両側)」、「側巷街道（迪化 街と隣接する $8 \mathrm{~m}$ の幅以下の)細街路) 、「第 1 街道 (涼州街、帰綏街、 民生西路の両側）」、第 2 街道（延平北路、南京西路の両側及び民生 西路の南側、環河北路の東側の一部) 小、水岸街道（民生西路の北側 及び環河北路の東側の一部)・の 5 種類に大別し、沿道の建築物の新 築の形態（図 6-E）、色彩及び立面などを規制している。

\section{(5) 容積移転制度の運用}

歴史性建築の保存及び伝統的街区の風貌の保全のために、容積移 転作業要点が制定され、a. 計画地区内の歷史性建築の敷地、b. 歴史 街区内の建築物の敷地、c. 伝統的街区の風貌を創造するため、市都 
市設計審議会によって許可される敷地において、未使用の容積の一 部または全部を一定の移転条件のもとに、台北市においての指定接

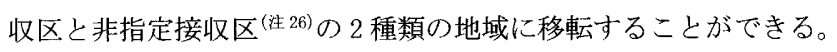

移転条件は、a. 特定専用区 1 種及び同 2 種は商業区に移転するこ と、3 種及び 4 種は住宅区に移転すること、b. 指定接収区に移転し た場合は、当該敷地の法定容積の $40 \%$ まで、非指定接収区に移転し た場合は、法定容積の $30 \%$ まを゙最大限とすること、c.容積移転す る際に、同じ敷地に移転することを条件として回数を限らずに容積 移転ができる。ただし、容積移転先の敷地条件によって当該敷地に 移転しきれない場合は、残された未使用容積を 1 回に限り他の敷地 に移転できる。

歷史性建築の場合は保護計画、非歷史性建築の場合は建築計画を それぞれ提出し、市都市設計審議会によって審議された後に、市都 市更新審議会によって容積移転の量が番議され、許可がおりた後に 移転が可能となる。2004 年 6 月現在までに、計 42 件 24 棟 (注27) の 容積移転の申請が許可されており、そのうち、歴史性建築の申請は 前述の通り 7 棟のみであり、開発を主な目的とした新築の件数が多 い。これは歴史性建築の修復は非歴史性建築物の修量より制限が厳 しく、また多額の費用もかかるからである。

一方、2002 年の都市計画法および都市計画容積移転実施辦法 (都 市計画容積移転害施方法) の改正により、公共施設保留地 (注 28) 指定された敷地も容積移転制度の適用対象となった。広い面積の公 共施設保留地の容積が移転できるようになったため、大稲埕地区に おける容積移転制度の運用に影響を与えることとなった。これに対 応して、市都市発展局は、大稲㘿地区における歴史性建築の容積移 転を促進するため、2003 年に容積移転作業要点を修正し、歴史性建 築の場合、前述の 3 つの移転条件の a. を解除し、また、市都市更新 審議会の業務を市都市設計審議会の業務と合併することにより、審 査のプロセスをより短縮した。

(6) 地区環境整備計画

1996 年から道路整備などが行われたことにより、大稲㘿地区の環 境が改善した。2000 年計画により、現在、特定専用区内に $2 つ 0$ 広 場がつくられたが、防災や交通などの問題に対寸る計画はまだ未策 定である。

\section{6. 大稲埕地区における歴史的環境保全計画案の変遷の特徵と課題}

1984 年案から 2000 年計画の決定に至るまで、その歴史的環境保 全の取り組みの経緯、各保全計画案の計画内容の変遷及び現行制度 の運用概況を整理把握した上で、その特徴及び課題について、計画 範讲、計画の目標、計画の策定にお忛る住民参加、計画内容、保全 事業及び制度の運用について考察すると、以下の通りである。

(1) 特徴

\section{(1) 街並みから街並みと周辺環境を包括した計画範囲への拡大}

1984 年案の保全範囲は、迪化街沿道の建築物のみと考えられてい たが、1990 年案では街並みと川の関係が検討され始め、保全範囲は 街並みだけでなく、淡水河河岸まで拡大された。また、1996 年案以 降の計画では、周辺の旧市街地も含め、迪化街の東側の延平北路の 両側まで拡大され、街並みと周辺環境を包括した計画範囲人と拡大 した。

(2) 街並み保全から保全と開発を包括した計画目的への変更
1984 年案及び 1990 年案を策定する際には、街並み保全及び伝統 産業の振興を目的としており、歴史的風貌の保全が主な目的であっ た。1996 年案以降では、住民からの開発要求に応じて、街並み保全 を考える一方で、保全と開発を包括した新たな計画目的が提示され た。2000 年計画の策定にあたり、歴史的風貌の保全及び地域発展の 促進を目的として、都市設計管制要点の制定によって街並み景観の 保全が確保されるとともに、容積移転作業要点の制定によって民間 の開発権益も確保されることとなった。

\section{(3) 計画策定における住民参加の重視}

大稲㘿地区における迪化街の拡幅から保全への計画変更は、市民、 NPO、専門家を主体とする保全運動の展開がきっかけとなり、その後 に市都市発展局が計画変更するに至った。

1984 年案の策定は専門家主導であったが、1990 年案の際には、大 稲㘿地区に初の情報提供の拠点を設置し、住民と直接コミュニケー ションがとられた。1995 年から市都市発展局が「迪化街工作室」を 永楽市場の 5 階に設置し、市職員を常駐させ、住民の意見聴取や計 画案の説明を行っている。そして 1996 年案においては、イベントの 開催などを通して住民と連携して計画を策定した。以上のように、 計画策定にあたり、住民参加が重視されてきており、住民参加の手 法が多様になっている。

\section{(4) ハード面の整備からハード・ソフト両面の重視へ}

1990 年案までは、主に歴史的建築物の保存や交通問題などのハー ド面の整備に関する提案が多かったが、1996 年案からは、住民参加 や産業振興などのソフト面の提案も増えてきており、ハード・ソフ 卜両面に渡る総合的計画となっている。

\section{(5) 事業の先行による住民の保全意識の向上}

前述の通り、台北市政府は住民の保全への反対に対して、1995 年 から迪化街の沿道地域を対象に一連のハードの景観整備事業を行う と共に、住民と連携してソフトの「年貨大街」イベントの開催を行 った。以上の動きにより、住民の保全意識は高まってきており、保 全計画の制定までに至った。

\section{(6) 都市計画関連制度を活用した歴史的環境の保全}

台湾では歴史的環境保全制度が十分に整備されていないため、大 稲㘿地区の事例は都市計画制度をもとに「特定専用区」の制定が検 討されることとなった。保全計画の策定に伴い都市設計制度や容積 移転制度などの都市計画関連制度が運用されることによって、大稲 㘿地区の保全は文化財保全の視点から都市景観保全の視点へと展開 し、単体的な建築物の保存から面的な保全へと拡大した。

(2) 課題

\section{(1) 容積移転制度の限界}

現行の 2000 年計画においては、保全と開発を包括した目的に応じ て容積移転制度を運用することとなったが、前述の通り、歴史性建 築の修復は非歴史性建築物の修景より制限が厳しく、また多額の費 用もかかるため、実際の運用状況においては歴史性建築の件数が少 なく、開発を主な目的とした新築の件数が多いという課題が浮上し ている。今後、容積移転制度の運用と合わせて歴史性建築の保存に 対する技術支援や修復経費の補助など長期的補助措置の制定が重要 と考えられる。また、容積移転制度の運用によって移転された地区 の景観にも大きく影響を与えているため、台北市における容積移転 の全体像を検討することも重要と考えられる。 
(2) 交通・オープンスペース・防災・住民参加などの視点を踏まえた

\section{より総合的な計画の策定の必要性}

前述の通り、2000 年計画は 1997 年案を参考にして、歴史性建築 の保存、都市設計制度及び容積移転制度などに重点がおかれて策定 されたが、交通やオープンスペースなどの地区環境整備計画はまだ 未策定である。大稲㘿地区は旧市街地であり、駐車スペースやオー プンスペースの不足、多数の細街路の存在による交通や防荻上の課 題がある。また、計画策定にあたり住民参加が重視されてきたが、 歴史的環境保全に関する地区のまとめ役としての住民組織は未成立 という課題も抱えている。以上に対して、交通、オープンスペース の整備、防災、住民参加などの視点を踏まえた総合的な計画を策定 することが重要と考えられる。

\section{(3) 市文化局との協働による検討}

大稲㘿地区の歴史的環境は、市都市発展局を中心に保全計画が策 定、関連事業が実施されたが、計画策定などにおいては文化資産の 担当部局である市文化局との連携が殆どなかった。今後、文化資産 保存法の第 4 次改正（草案）に扔ける、面的な保全制度の整備に伴 い(注 29)、市都市発展局が市文化局と協働して検討することが必要と 考えられる。

\section{7. まとめ}

台北市大稲㘿地区では 1984 年から約十数年を経て、様々な保全計 画が検討された上で、2000 年計画の策定に至った。その変遷の特徵 として、街並みから街並みと周辺環境を包括した計画範囲人の拡大、 街並み保全から保全と開発を包括した計画目的一の変更、計画策定 における住民参加の重視、ハード面の整備からハード・ソフト両面 の重視、事業の先行による住民の保全意識の向上、都市計画関連制 度の運用による歴史的罢境の保全などの特徴が举げられる。一方、 容積移転制度の限界、交通・オープンスペース・防災・住民参加な どの視点を踏まえたより総合的な計画の策定の必要性、市文化局と の協働による検討などが課題である。現在の 2000 年計画のその後の 運用状況について、引き続き考察することが今後の研究課題である。 謝辞

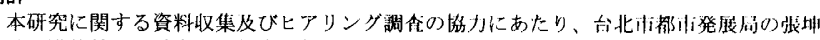

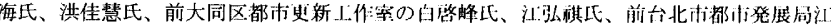

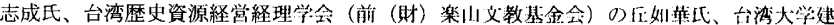

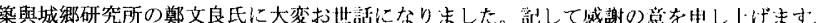
本研究の一部は平成 15 年度笹川科学研究比成金により研究助成を受汀て行独机した。

【注秋】

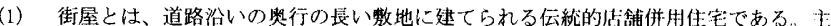
に隣家と壁を共有して速続している。

（2）台湾で「街」と洼街を意味する。迪化街は一段と二段に分かれているが、本稍の

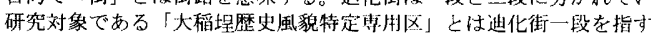

（3）都市計画法によって、都市計画を策定する際、実際の状洗に心じて特定専鹏区を制 定することができる(都市計画法第 32 条)。

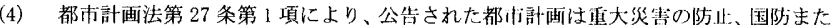
は経済の発展のため、当該地区の直轄市、県 (市) (局)または鄉、鎮、其轄林公所 によって実際の状況に応じて計画を変更することができる。

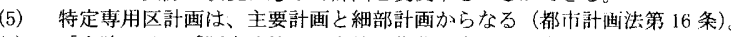

（6）「古踽」及び「歴史建築」の定義は集落、市街地も含めているが、運用のための関 連制度が定められていないため、実際の運用の刘象は殆ど䍩体の建造物である。 た、「保存区」法、都市計画法、区域計画法或いは国家公園法に基づいて地区指定を することとなるが、文資法による独自の地区指定がまだ整備されておらず課題とな つている。

（7）例えば、都市計画法によって特定専用区として指定された歴史的街並みには、本研 究の対象とする大稻埕歴史風貌特定専用区の他、澎湖県馬公市中央街文化風貌特定 専用区などがある。また、国家公園法によって国家公園の指定として保全された伝 統的集落には、金門国家公園がある。

（8）台湾では、発展権移転、容積移転などと呼ばれているが、本稿では台湾の文化資産 保存法及び都市計画法による容樍移転という

（9）迪化街の街屋に関する論文としては、例えば李東明，波多野純：台北市迪化街にお けるアータード付き街屋建築の成立々変遷, 日本建築学会計画系論文集, pp. 237-242, 2001 年 9 月がある。

（10）台湾の既往研究としては、参考文献 1）～5）があげられる。
（11）筆者らが発表した論文は以下の通りである。

(1) 浅野聡・黄国鳳：台湾的歴史市街地「进化街」保存的国際意義, 空問, 第 19 期, pp. $16 \sim 18,1991.2$

(2) 浅野聡・黄国鳳・卢沼幸市: 台北市・迪化街の歴史的㻴境保全に関する研究之 の $1 \sim そ の 3$, 日本建築学会学術梗概集, F-1, pp. 47 52, 1990. 10

(3) 浅野聡・黄国鳳・高橋正樹・戸沼幸市：台北市・迪化街の歷史的環境保全に関 卞る研究 その 4 その 6, 日本建築学会学術梗概集, F-1，pp. 47 52, 1991.9

（12）台湾で行った文献調查及びヒアリング調查の日時、対象及び内容については以下の 通りである。

(1) 台北市都市発展局大同区都市更新工作室白啓峰氏、江弘祺氏：大稲烓歴史風貌 特定尃用区都市計画の策定経緯及び計画の執行にあたる市都市発展局の役割 (2000 年12月12日)。

(2) 台北市都市発剭局大同区都市更新工作室江弘稘氏、張坤海氏 : 大稻堭歴史風貌

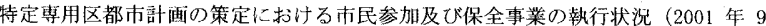
月 10 日, 13 日)。

(3) 台北市都市発展局大同区都市更新工作室張坤海氏 : 大稻㘿歴史風貌特定専用区 計画に拈以る計画内容の確認 (2002 年6月 2 日)。

(4) 台北市都市発展局大同区都市更新工作室張坤游氏：大稻垾歴史風貌特定専用区 計画の運用成果（2004 年1月9日）。

また、2001年 12 月 17 日に（財）楽山文教基金会及び台北市都市発展局が共催し た「大稻堤的昨日、今日、明日国際研討会 (大稲㘿的昨日、今日、明日国際シンポ ジウム)」に出席して綞演した。

(13) 参考文献 5)を参若にして作成した。

（14）糜史性建築とは、台北市の独自制度である「台北市都市更新地区にお㚈る歴史性建 筑の認定及び保護に対する補助に関する裂点」によって認定される歴史的建築物で 声。

（1.5）台溜の街虚に执いては、前面道路に対する奥行き力问の建筑物の棟の単位として 「進」や「洛」があり、本文中の図3に示す通り、前百道路加ら1棟目を第 1 進、

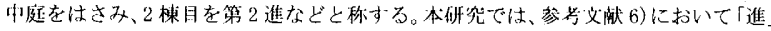
の名称が伐州されたため、「進」の名称を㺫いる。

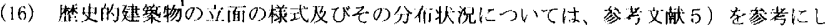
ている。

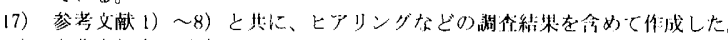

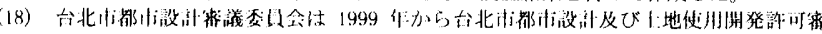
硪委以会八政糺した

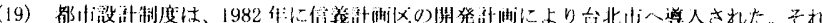

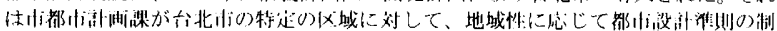

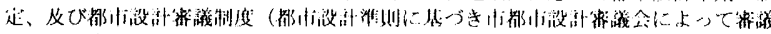

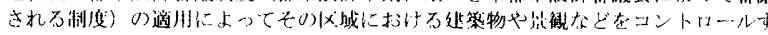
る制度である。

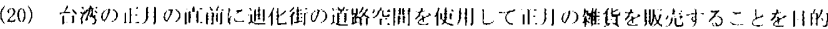
としたイベントである

(21）參考文献 1）～7）老药考にしている。

(22) 淮:(21) と间梯

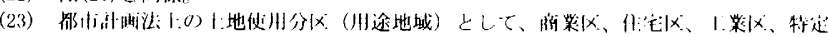
少月冈ならが这められることがでさる。

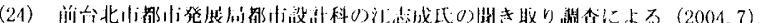

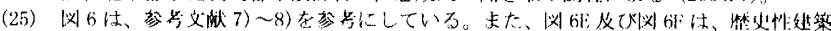

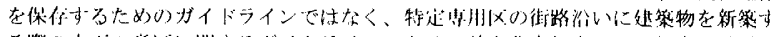

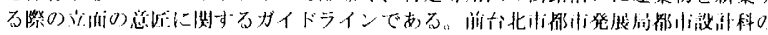

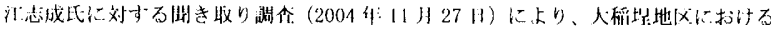

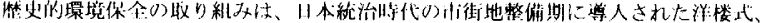

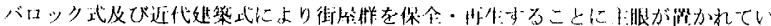

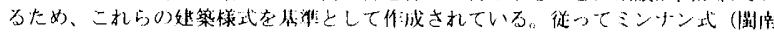

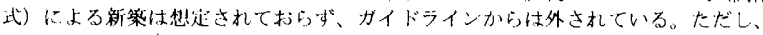

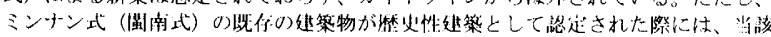
建案物の様式をも，とに修往を行っている

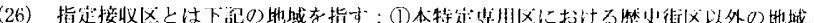

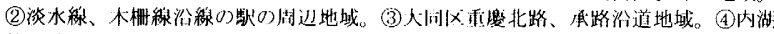

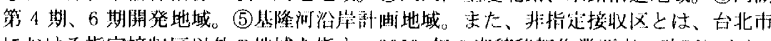

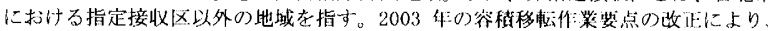

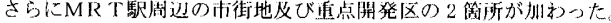

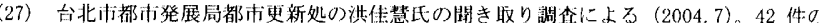

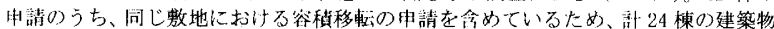
の敖地となっている。

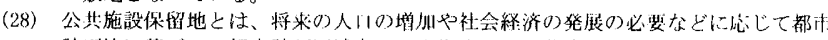

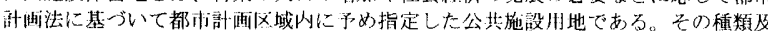

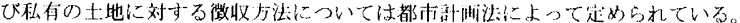

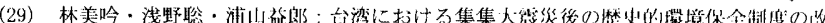

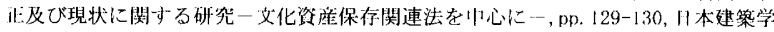
会計画系綸文集 第 573 号, 2003

[参考文献]

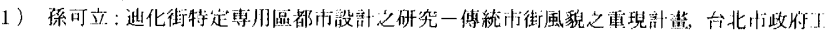
務局都甫部書処，1984

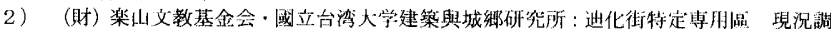
查及発展可行性研究, 台北市政胕工稀胢都市計畫処, 1989

3) 中原大学建策研究所都市設計研究窒: 大稻嚗特定専用區初步発展構想及都市設部之研 究，台北训政府工務局都市計畫処，1990

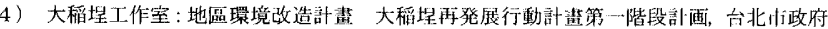
市都市発展局，1996

5）中華民國住宅発展協會：大稻旺特定専用區整体発展部黄 総絬報告書, 台北市政府市 都市発展局, 1997

6）台北市政府:變更台北市大同區大稻㘿付近地區為大稲㘿歴戈風貌特定尃用区主要計畫 案, 2000

7）台北市政府：擬定台北市大同區大稻垾歴史風貌特定専用區細部計畫案，2000

8）台北市都市発展局：大稲㘿歴史風貌特定専用区簡介，2001

9）台北市政府市都市発展局：城市的歴史魅力，2003 